\title{
A concise drug alerting rule set for Chinese hospitals and its application in computerized physician order entry (CPOE)
}

\author{
Yinsheng Zhang ${ }^{1 *}$, Xin Long ${ }^{2}$, Weihong Chen ${ }^{3}$, Haomin Li ${ }^{4 *}$, Huilong Duan ${ }^{2}$ and Qian Shang ${ }^{5}$
}

\begin{abstract}
Background: A minimized and concise drug alerting rule set can be effective in reducing alert fatigue.

Objectives: This study aims to develop and evaluate a concise drug alerting rule set for Chinese hospitals. The rule set covers not only western medicine, but also Chinese patent medicine that is widely used in Chinese hospitals.

Setting: A 2600-bed general hospital in China.

Methods: In order to implement the drug rule set in clinical information settings, an information model for drug rules was designed and a rule authoring tool was developed accordingly. With this authoring tool, clinical pharmacists built a computerized rule set that contains 150 most widely used and error-prone drugs. Based on this rule set, a medication-related clinical decision support application was built in CPOE. Drug alert data between 2013/12/25 and 2015/07/01 were used to evaluate the effect of the rule set.

Main outcome measure: Number of alerts, number of corrected/overridden alerts, accept/override rate.

Results: Totally 18,666 alerts were fired and 2803 alerts were overridden. Overall override rate is $15.0 \%$ (2803/18666) and accept rate is $85.0 \%$.

Conclusions: The rule set has been well received by physicians and can be used as a preliminary medical order screening tool to reduce pharmacists' workload. For Chinese hospitals, this rule set can serve as a starter kit for building their own pharmaceutical systems or as a reference to tier commercial rule set.
\end{abstract}

Keywords: Medication-related clinical decision support, Chinese patent medicine, Drug alerting rule, Alert fatigue

\section{Background}

Computerized physician order entry (CPOE) with medication-related clinical decision support (CDS) is an effective solution to reduce drug-related problems and pharmacist workload (Hammar et al. 2015; Claus et al. 2015). Most medication-related decision support functions, such as dosage checking and drug-drug interaction (DDI) checking, are typically implemented by a set

\footnotetext{
*Correspondence: zhangys@zjgsu.edu.cn; hmli@zju.edu.cn ${ }^{1}$ School of Computer Science and Information Engineering, Zhejiang Gongshang University, Hangzhou 310018, Zhejiang,

People's Republic of China

${ }^{4}$ Children's Hospital, Institute of Translational Medicine, School of Medicine, Zhejiang University, Hangzhou 310058, Zhejiang, People's Republic of China

Full list of author information is available at the end of the article
}

of computerized drug alerting rules. One major problem faced by drug alerting rules is the alert fatigue (Nanji et al. 2014), which is usually caused by highly exhaustive and sensitive rules. Recent related work shows override rates can be as high as 53.6\% (Nanji et al. 2014), $87.6 \%$ (Topaz et al. 2015), and 93\% (Bryant et al. 2013) respectively. To address this issue, lots of work has been focused on constructing minimized and concise drug rule sets. For example, Shah et al. (2006) built a tiered medication knowledge subset from a commercial knowledge base. The subset contains clinical significant drug contraindications, and only interrupts physicians for severe alerts. Phansalkar et al. (2012) developed a minimum set of 15 high-severity, clinically significant DDIs from several commercial knowledge bases. Classen et al. (2011) 
identified 7 most common DDIs by reviewing multiple sources. The public DDI knowledge base SFINX (Swedish, Finnish, INteraction X-referencing) tiers DDIs according to clinical significance (A-D), which enables threshold settings for automated warnings (Andersson et al. 2015).

\section{Aim of the study}

The aim of this study to build and evaluate a concise rule set suitable for Chinese hospitals. Compared to existing related work, this rule set not only covers the western medicine, but also includes various Chinese patent medicine (CPM) that is extensively used by Chinese hospitals. For example, a typical Chinese hospital (DaYi Hospital, ShanXi Province, China) uses 1981 drugs, and 462 (23.3\%) are Chinese patent medicine.

\section{Ethical approval}

This study was approved by the medical ethics committee of DaYi Hospital. All collected data have been de-identified by the information department of the hospital.

\section{Methods}

\section{Settings and materials}

DaYi Hospital was established in 2011 and is the largest general hospital (2600-bed) in ShanXi Province, China. Until 2013, all the drug checking work in DaYi was performed manually by clinical pharmacists. At the drug dispensing time, the pharmacists would inspect medication orders submitted by the physicians. Unqualified orders would be returned to physicians and recorded by the pharmacists. The recorded medication errors between 2011 and 2013 were used to analyze the most frequent and error-prone drug rules. These records are the initial resource for building the concise rule set.

In 2013, we initiated the KTP (Knowledge Translation Platform) project (Zhang et al. 2015). One of KTP's goals is to build a medication-related CDS for CPOE, in order to help pharmacists reduce work load and assist the drug checking process. At the beginning of KTP, a preliminary question is: whether to develop own medication-related CDS or use a commercial one. Although there are already mature commercial products on the Chinese market, e.g. Wolters Kluwer/Medicom PASS (Prescription Automatic Screening System), we have our own considerations for not choosing such off-the-shelf systems. (1) Although the rule base of commercial products may be much more comprehensive and detailed, it is still necessary to tier and routinely tailor the complete rule set to suit local hospital situations. For pharmacists, there is not much workload advantage over maintaining a local-developed rule set. (2) From the perspective of the KTP project, the pharmaceutical knowledge is an inseparable part of the entire knowledge base. Inside the KTP knowledge base, there are semantic relations between drug and other medical entities. For example, many clinical rules (e.g. if [Use of Aspirin] $==$ true $\|$ [Use of Clopidogrel] $==$ true, recommend [INR monitor]) and clinical treatment protocols (predefined order sets or clinical pathways) involves drug entities. If using third-party products, even if the vendors open their knowledge base or provide external access interfaces, the integration and interaction between different systems (e.g. mapping of drug entities across systems) can be complex and effort-taking. Therefore, we decided to develop an own system.

\section{Information model}

To implement a computerized rule set, an information model of drug alerting rules is designed (Fig. 1). It defines 11 rule types (Table 1 ), including dosage (single intake), daily dosage (accumulated intake), administration route, frequency, skin test, dissolvent, dissolvent dosage, DDI, contra-indication, and prescription restriction.

These rule types are designed according to pharmacists' drug checking requirements. However, there are also other rule types, such as personalized dosing algorithms (e.g. children or elder patients with different body weights and body surface areas, or patients with renal insufficiency based on creatinine clearance). In the current development phase, we haven't supported such rules because they require lots of patient context data, such as body weight, body surface area, $\mathrm{Crcl}$ rate, etc. These data mostly reside in heterogeneous formats in external systems, such as HIS (Hospital Information System), LIS

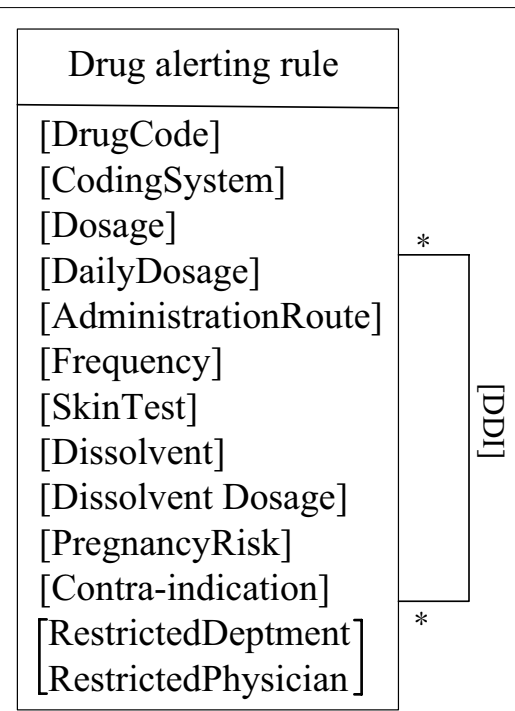

Fig. 1 The Information model for drug alerting rules 


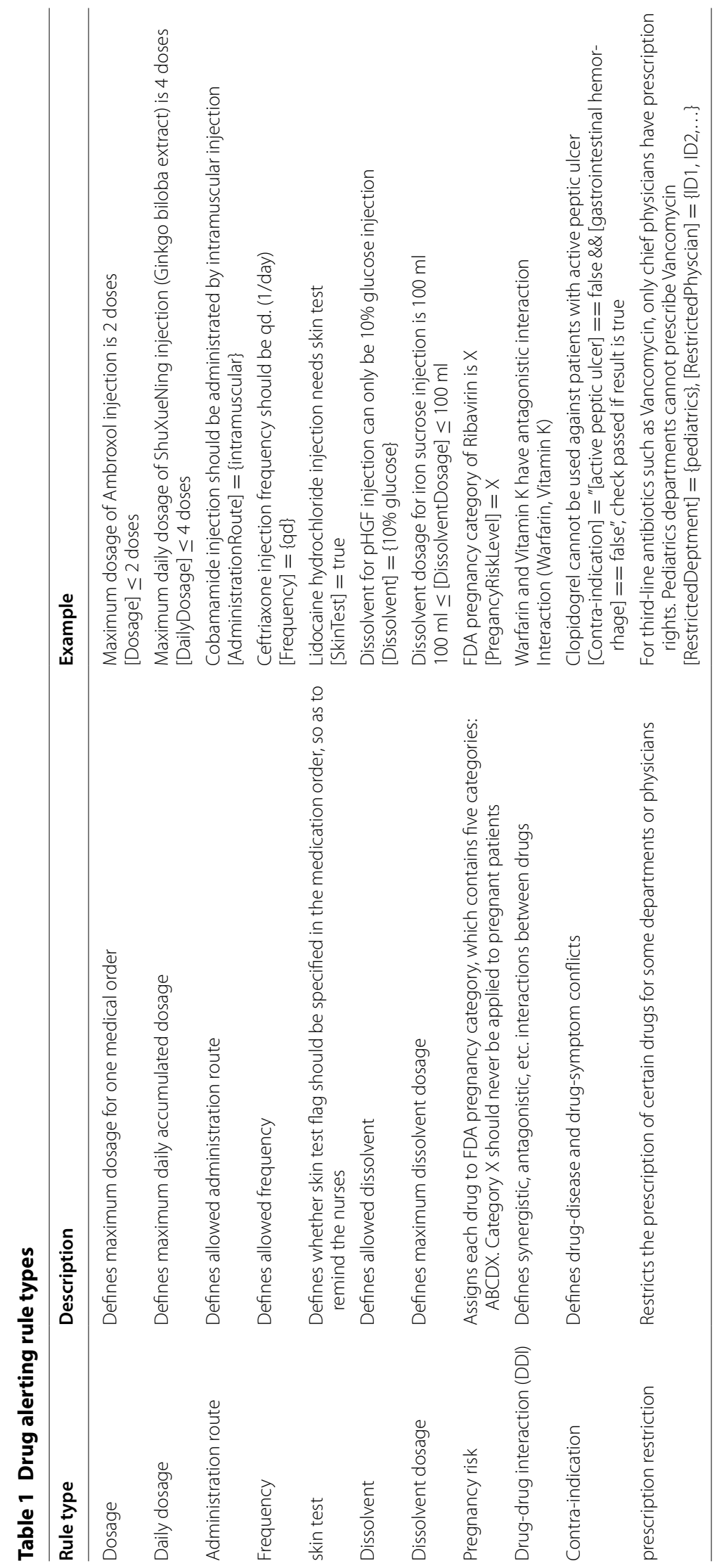


(Laboratory Information System), EMR (Electronic Medical Record), etc. How to extract high-quality and wellstructured data in expected formats from various sources is a non-trivial task. In the next development phase, we will try to solve this data acquisition problem and support more rule types.

\section{Authoring tool}

Based on the above information model, the database schema for drug alerting rules can be decided, and a corresponding rule authoring tool has been developed (Fig. 2). The tool was developed as a web-based application.

\section{Results}

\section{Drug alerting rule set}

Based on the recorded medication errors between 2011 and 2013, the pharmacists used the rule authoring tool to define a rule set that was able to cover the most widely used and error-prone drugs. The first version of the rule set was created in June 2013, and contained 150 drugs. The detailed rule set is provided in "Appendix".

\section{Medication-related CDS based on the rule set}

With the rule set, a medication-related clinical decision support was developed and integrated into CPOE (Fig. 3). Reasoning of the rules is executed by a home-grown rule engine (refer to http://ktp.brahma.top/Display/TestRuleEngine, http://ktp.brahma.top/Pages/Evaluation/ RuleEngine/Index.html). The CPOE was also developed by our research team, under the product name "MIAS (Medical Information Automation System)". The interaction between CPOE and CDS was implemented by web services. Whenever the physician submits orders, CPOE will call the drug checking web service of CDS to trigger the rule engine. CDS-detected alerts are then returned

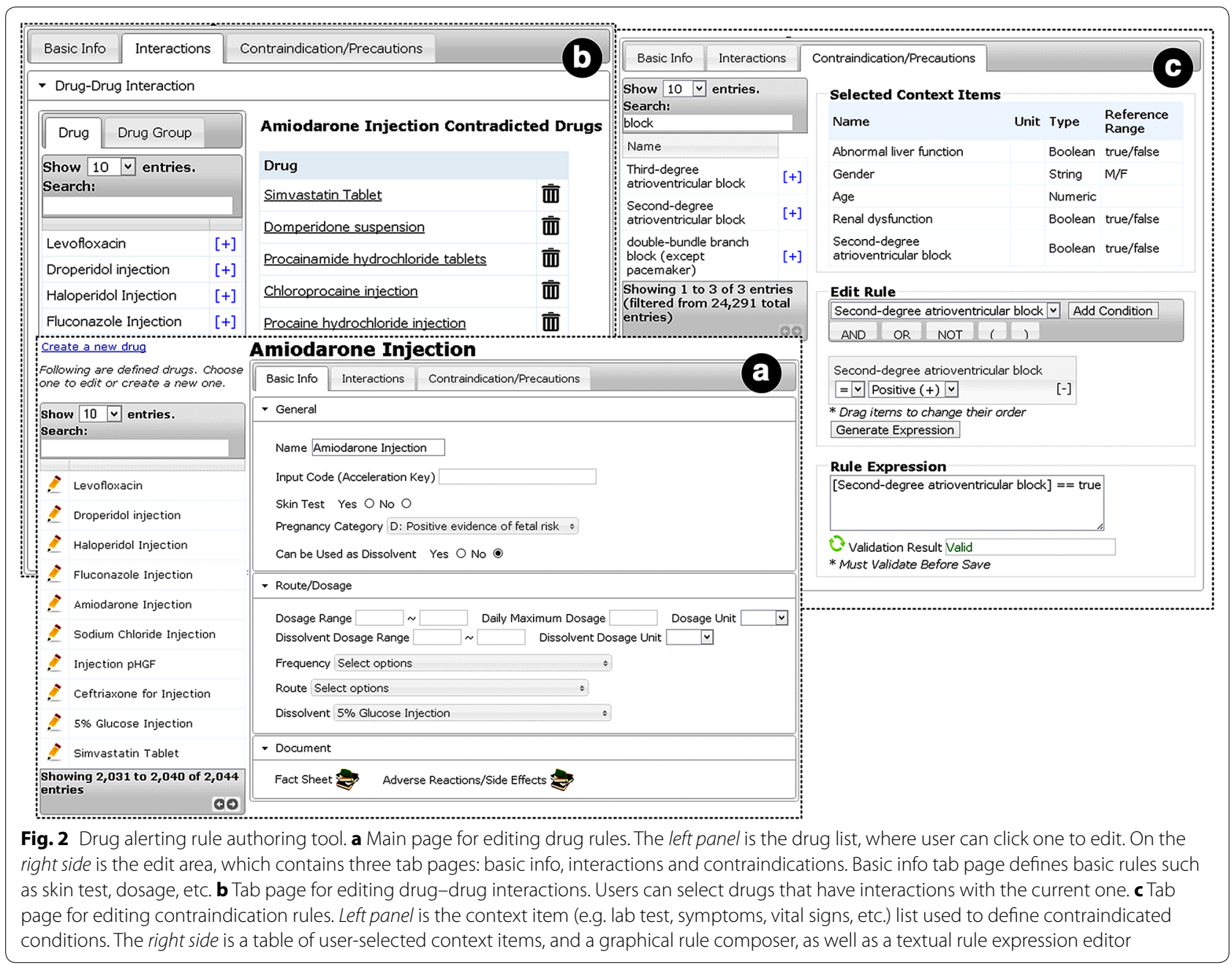




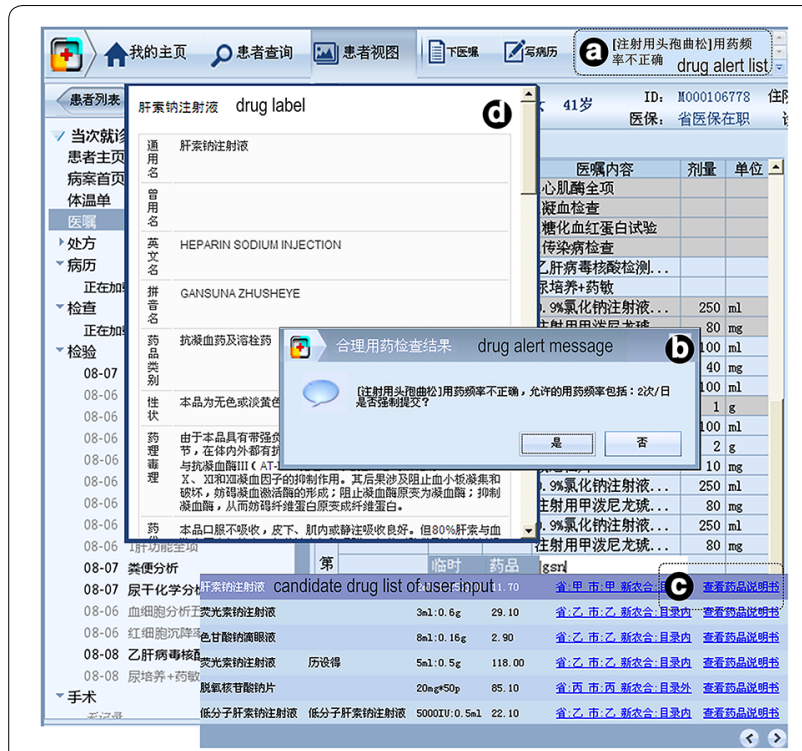

Fig. 3 Medication-related clinical decision support in CPOE. a Notification area for drug alerts. User can review and process all triggered drug alerts in this area. b Drug alert message. c Infobutton for drug labels. d Retrieved drug label by Infobutton

to CPOE, and CPOE displays them to the physician as warnings (Fig. 3b). The physician can either cancel order submission or override the alert. All detected alerts are also sent to the notification area (Fig. 3a) for review. In exceptional cases due to patient status, physicians may state their reasons for overriding the alert. While reviewing the drug alerts, physicians can use infobutton (Fig. 3c) to retrieve related drug labels (Fig. 3d). For pharmacists, we provide a backend web portal for viewing the status (accepted or overridden) and override reason for each alert. The information flow of drug alert status is automatically directed and tracked by the system, which has greatly reduced the necessity of face-to-face communication and telephone calls between physicians and pharmacists.

In this system, only physicians have the right to change the status of an alert (accept or override). Pharmacist only have read-only rights for alert statuses, but they can edit (increase threshold or change rule content) or deactivate corresponding rules if they found many occurrences of an unreasonable alert.

\section{Evaluation of the rule set in CPOE}

The computerized rule set was first implemented in the inpatient CPOE on 2013/12/25 (The outpatient CPOE was provided by another vendor, and had not been integrated with our system). Until now, the system has been used in 49 inpatient departments for more than 2 years. In order to evaluate the actual effect of the rule set, system log data between 2013/12/25 and 2015/07/01 were collected. During this period, totally 68,182 inpatient visits were enrolled into the system and 2,747,140 medication orders were submitted.

For the submitted medication errors, totally 18,666 alerts were detected by the CDS, and 2803 alerts were overridden by physicians. Therefore, the overall override rate is $15.0 \%(2803 / 18,666)$, and accept rate is $85 \%$. Among the 18,666 alerts, Chinese patent medicine (CPM) takes up $38.4 \%$ (7168 in 18,666).

According to Tables 2 and 3, several results caught our attention and we further analyzed these results.

1. Among the detected alerts, "daily dosage" rule type has the highest alert occurrence rate (12,212 alerts in total 18,666). We dived into the "daily dosage" alerts, and found four of the top five drugs are CPM, i.e. "Salvia TMP injection (4039 alerts)", "Thin Chi glycopeptide injection (1050 alerts)", "Shuxuening injection (876 alerts)" and "Fufangkushen Injection (761 alerts)", which are responsible for the majority of "daily dosage" alerts. CPM is mostly extracted or manufactured from Chinese traditional herbs. Compared to western synthesized chemical medicine, though herbs take much longer time to take effect, they also have fewer side effects and adverse reactions. In fact, CPM usually plays an auxiliary or supportive role in treatment regimens. For this reason, some physicians relaxed their vigilance and didn't pay enough attention when using CPM. This also explains why CPM has a noticeable percentage in all the detected alerts (38.4\%).

2. The "dissolvent dosage" rule type has the highest override rate $(67.9 \%)$. The $67.9 \%$ override rate is remarkably high compared to other rule types, which means about $2 / 3$ "dissolvent dosage" alerts have been overridden. We consulted with the clinical pharmacists, and found many alerts were related to patients with certain conditions, e.g. renal deficiency or heart failure. For such patients, it is reasonable to use smaller dosage than required by the drug fact sheet. Such false-positive cases have added up to the overridden alerts. To address this issue, we are currently considering using more patient context data to exclude such false-positive alerts. 
Table 2 Drug alert analysis

\begin{tabular}{|c|c|c|c|c|c|}
\hline Drug name & Drug name (Chinese) & Alert type & Alerts & Overridden alerts & Override rate $(\%)$ \\
\hline Ambroxol injection & 氨溴索注射液 & Daily dosage & 4938 & 22 & 0.4 \\
\hline Salvia TMP injection & 丹参川芎嗪注射液 & Daily dosage & 4039 & 0 & 0.0 \\
\hline Injection esomeprazole & 注射用埃索美拉唑 & Dissolvent dosage & 1261 & 1239 & 98.3 \\
\hline Thin Chi glycopeptide injection & 薄芝糖肽注射液 & Daily dosage & 1050 & 2 & 0.2 \\
\hline Shuxuening injection & 舒血宁注射液 & Daily dosage & 876 & 0 & 0.0 \\
\hline Fufangkushen injection & 复方苦参注射液 & Daily dosage & 761 & 4 & 0.5 \\
\hline Lidocaine hydrochloride injection & 盐酸利多卡因注射液 & Skin test & 691 & 287 & 41.5 \\
\hline Injection cefathiamidine & 注射用头孢硫脒 & Daily dosage & 488 & 0 & 0.0 \\
\hline Injection thymopentin & 注射用胸腺五肽 & Administration route & 413 & 277 & 67.1 \\
\hline Calcium gluconate injection & 葡萄糖酸钻注射液 & Dissolvent & 307 & 0 & 0.0 \\
\hline Iron sucrose injection & 蔗糖铁注射液 & Dissolvent dosage & 298 & 0 & 0.0 \\
\hline Injection ambroxol & 注射用氨溴索 & Administration route & 248 & 0 & 0.0 \\
\hline Injection aminophylline & 氨茶碱注射液 & Dissolvent & 229 & 161 & 70.3 \\
\hline Injection pantoprazole & 注射用泮托拉唑 & Dissolvent dosage & 219 & 111 & 50.7 \\
\hline Yinxingdamo injection & 银杏达莫注射液 & Dissolvent dosage & 203 & 102 & 50.2 \\
\hline Injection omeprazole & 注射用奥美拉唑 & Administration route & 198 & 191 & 96.5 \\
\hline Injection pantoprazole & 注射用泮托拉唑 & Administration route & 133 & 46 & 34.6 \\
\hline Injection of fat-soluble vitamins II & $\begin{array}{l}\text { 注射用脂溶性维生 } \\
\text { 素II }\end{array}$ & Dissolvent & 131 & 10 & 7.6 \\
\hline Ceftriaxone for injection & 注射用头孢曲松 & Frequency & 116 & 56 & 48.3 \\
\hline Injection cefamandole ester & 注射用头孢孟多酯 & Prescription restriction & 113 & 0 & 0.0 \\
\hline Injection pancreatic kallikrein & 注射用胰激肽原酶 & Administration route & 113 & 0 & 0.0 \\
\hline Leucovorin injection & 亚叶酸钙注射液 & Administration route & 112 & 0 & 0.0 \\
\hline Injection cefoxitin & 注射用头孢西丁 & Prescription restriction & 110 & 0 & 0.0 \\
\hline Injection omeprazole & 注射用奥美拉唑 & Dissolvent dosage & 103 & 61 & 59.2 \\
\hline Oxytocin injection & 缩宫素注射液 & Dissolvent & 96 & 0 & 0.0 \\
\hline Heparin sodium injection & 肝素钠注射液 & Administration route & 91 & 0 & 0.0 \\
\hline Sodium for injection cefodizime & 注射用头孢地嗪钠 & Prescription restriction & 87 & 0 & 0.0 \\
\hline Alprostadil injection & 前列地尔注射液 & Administration route & 80 & 28 & 35.0 \\
\hline Furosemide injection & 呋塞米注射液 & Dissolvent & 70 & 51 & 72.9 \\
\hline Injection esomeprazole & 注射用埃索美拉唑 & Frequency & 60 & 0 & 0.0 \\
\hline Salvia TMP injection & 丹参川芎嗪注射液 & Dissolvent dosage & 57 & 0 & 0.0 \\
\hline $\begin{array}{l}\text { Injectable piperacillin sodium and tazobactam } \\
\text { sodium }\end{array}$ & $\begin{array}{l}\text { 注射用哌拉西林钠他 } \\
\text { 唑巴坦钠 }\end{array}$ & Prescription restriction & 53 & 0 & 0.0 \\
\hline Cefoperazone sulbactam & $\begin{array}{l}\text { 注射用头孢哌酮舒 } \\
\text { 巴坦 }\end{array}$ & Prescription restriction & 51 & 0 & 0.0 \\
\hline Kangai injection & 康艾注射液 & Dissolvent dosage & 47 & 0 & 0.0 \\
\hline Leucovorin injection & 亚叶酸钙注射液 & Frequency & 43 & 0 & 0.0 \\
\hline Levofloxacin injection & 左氧氟沙星注射液 & Dissolvent dosage & 38 & 21 & 55.3 \\
\hline Injection torasemide & 注射用托拉塞米 & Frequency & 38 & 0 & 0.0 \\
\hline Large plants Rhodiola injection & 大株红景天注射液 & Dissolvent dosage & 37 & 0 & 0.0 \\
\hline Cefoperazone & 注射用头孢哌酮 & Prescription restriction & 36 & 0 & 0.0 \\
\hline Xuebijing injection & 血必净注射液 & Dissolvent dosage & 36 & 26 & 72.2 \\
\hline Injection of fat-soluble vitamins || & $\begin{array}{l}\text { 注射用脂溶性维生 } \\
\text { 素II }\end{array}$ & Daily dosage & 33 & 3 & 9.1 \\
\hline Ceftazidime for injection & 注射用头孢他啶 & Prescription restriction & 30 & 0 & 0.0 \\
\hline Injection imipenem cilastatin sodium & $\begin{array}{l}\text { 注射用亚胺培南西司 } \\
\text { 他丁钠 }\end{array}$ & Prescription restriction & 28 & 0 & 0.0 \\
\hline Sodium for injection aescinate & 注射用七叶㿝苷钠 & Daily dosage & 24 & 3 & 12.5 \\
\hline Torasemide injection & 托拉塞米注射液 & Frequency & 23 & 0 & 0.0 \\
\hline Shuxuening injection & 舒血宁注射液 & Dissolvent & 21 & 17 & 81.0 \\
\hline
\end{tabular}


Table 2 continued

\begin{tabular}{|c|c|c|c|c|c|}
\hline Drug name & Drug name (Chinese) & Alert type & Alerts & Overridden alerts & Override rate (\%) \\
\hline Injection of water-soluble vitamins & 注射用水溶性维生素 & Dosage & 21 & 0 & 0.0 \\
\hline Amiodarone injection & 胺碘酮注射液 & Dissolvent & 20 & 15 & 75.0 \\
\hline Injection ulinastatin & 注射用乌司他丁 & Frequency & 20 & 0 & 0.0 \\
\hline Meropenem for injection & 注射用美罗培南 & Prescription restriction & 19 & 0 & 0.0 \\
\hline Polyene phosphatidylcholine injection & $\begin{array}{l}\text { 多烯磷脂酰胆碱注 } \\
\text { 射液 }\end{array}$ & Dissolvent & 19 & 11 & 57.9 \\
\hline Injection pantoprazole & 注射用泮托拉唑 & Dissolvent & 18 & 8 & 44.4 \\
\hline Insulin injection & 胰岛素注射液 & $\mathrm{DDI}$ & 17 & 3 & 17.6 \\
\hline Fluconazole injection & 氟康唑注射液 & Prescription restriction & 16 & 0 & 0.0 \\
\hline Injection esomeprazole & 注射用埃索美拉唑 & Dosage & 15 & 0 & 0.0 \\
\hline Sodium for injection aescinate & 注射用七叶㿝苷钠 & Dosage & 15 & 0 & 0.0 \\
\hline Vancomycin injection & 注射用万古霉素 & Prescription restriction & 14 & 0 & 0.0 \\
\hline Vitamin C injection & 维生素C注射液 & $\mathrm{DDI}$ & 13 & 3 & 23.1 \\
\hline Injection omeprazole & 注射用奥美拉唑 & Dissolvent & 13 & 12 & 92.3 \\
\hline Methylprednisolone sodium succinate injection & $\begin{array}{l}\text { 注射用甲泼尼龙琥 } \\
\text { 珀酸钠 }\end{array}$ & DDI & 11 & 1 & 9.1 \\
\hline Injection carbazochrome sodium sulfonate & 注射用卡络磺钠 & Dissolvent & 11 & 7 & 63.6 \\
\hline Itraconazole oral solution & 伊曲康唑口服液 & Prescription restriction & 10 & 0 & 0.0 \\
\hline Fufangkushen injection & 复方苦参注射液 & Dosage & 10 & 0 & 0.0 \\
\hline Flurbiprofen injection & 氟比洛芬酯注射液 & Dosage & 10 & 0 & 0.0 \\
\hline Injection lentinan & 注射用香菇多糖 & Dosage & 10 & 0 & 0.0 \\
\hline \multicolumn{3}{|c|}{ Other low occurrence drug alerts (i.e. fired alert count <10) } & 155 & 25 & 16.1 \\
\hline \multicolumn{3}{|l|}{ Total } & 18,666 & 2803 & 15.0 \\
\hline
\end{tabular}

3. The "skin test" rule type has the second highest override rate (41.5\%). Investigation reveals that this high override rate is caused by the discrepancy in physicians' understanding of the "skin test" rule. In this system, the skin test rule is not designed as a mandatory requirement for the current specific patient, but a general risk reminder for nurses. That means, if there is potential allergic risk (either from medical literature or drug fact sheet) for a certain drug, physicians should set the skin test flag for corresponding medication orders. If not, the skin test rule will give an alert. When it comes to the drug administrating phase, the nurses will investigate this flag as well as patient's specific conditions (e.g. known allergy history towards certain drugs) to judge whether skin test is needed. However, many physicians treated the "skin test" rule as patient-specific flags, i.e. if a certain drug has potential allergic risk, but the physician already knows the current patient is not allergic to this drug, he/she will not set the flag and override the skin test alert.
Besides the above analysis for certain rule types, there are also high alert occurrence and override rates for several individual drugs, which are caused by different reasons and need case-by-case investigation. Base on these periodical retrospective analyses, pharmacists can continually improve the rule set (e.g. change threshold, revise rule content, deactivate rules) to better suit clinical use.

\section{Discussion}

The primary contribution of this study is a concise drug alerting rule set oriented to Chinese hospitals. As the rule set was built based on the historical data from a large-scale (2600-bed) general hospital with high patient throughput (e.g. 68,182 inpatient visits from 2013/12/25 to $2015 / 07 / 01$ ), the rule set should be able to reflect the medication use profile of large populations and may serve as a reference for other Chinese hospitals.

In this study, the computerized rule set can be used as a "preliminary screening tool" against physicians' medication orders. In DaYi Hospital, pharmacists need to 
Table 3 drug alert analysis grouped by rule types

\begin{tabular}{lrrr}
\hline Alert type & Alerts & Overridden alerts & Override rate (\%) \\
\hline Daily dosage & 12,212 & 34 & 0.3 \\
Dissolvent dosage & 2299 & 1560 & 67.9 \\
Administration route & 1391 & 542 & 39.0 \\
Dissolvent & 964 & 312 & 32.4 \\
Skin test & 691 & 287 & 41.5 \\
Prescription restriction & 595 & 0 & 0.0 \\
Frequency & 300 & 56 & 18.7 \\
Dosage & 151 & 5 & 3.3 \\
DDI & 63 & 7 & 11.1 \\
Total & 18,666 & 2803 & 15.0 \\
\hline
\end{tabular}

check 4968 medication orders per day on average, and unqualified orders have to be returned to physicians. This is a time-consuming and laborious work. With the drug alerting CDS, many potential mistakes can be ruled out before they reach the final checkpoint of pharmacists. According to the evaluation result, physicians have revised $85 \%$ of detected medication orders. In the long run, the system will not only alleviate the workload of pharmacists (many drug use errors can be revised by the physicians without pharmacists' intervention) but also enhance the workflow efficiency (avoid the "reject-reviseresubmit" process).

This study has several limitations or arguments:

1. The proposed rule set is not suitable for procedural drug rules. For example, the preparation of azithromycin solution is a multi-step procedure. First, azithromycin is dissolved with sterilized water to formulate into $0.1 \mathrm{~g} / \mathrm{ml}$. Then, add it to $250-500 \mathrm{ml} 0.9 \% \mathrm{NaCl}$ or $5 \%$ glucose solution to get a $1.0-2.0 \mathrm{mg} / \mathrm{ml}$ concentration. This procedural logic cannot be easily represented as a single succinct dissolvent rule.

2. The current rule set doesn't support complex personalized dosing algorithms. In certain contexts, such as children or elder patients with different body weights and body surface areas, or patients with renal insufficiency based on creatinine clearance, more complicated personalized dosing algorithms are needed. To support them, the information model needs further extension to represent such individualized knowledge.
3. DDI rule subtyping. In current system implementation, all DDI rules are treated as one rule type. However, it's better to design more DDI sub-types in order to achieve more fine-grained alerts. For example, the SFINX project (Andersson et al. 2015) tiers DDIs according to clinical significance (A-D), which enables fine-grained threshold settings for automated warnings.

4. Lack of complete evaluation. In this study, the accept and override rates can be easily calculated from the log data. However, it is not so easy to calculate accuracy and specificity, which requires reviewing every overridden alert in order to identify true positives and false positives. In the future, we will build a "closed-looped" alert tracking workflow, in which the state changes (either by physicians or pharmacists) and change reasons (e.g. why physician override an alert, and why pharmacists reject overriding an alert) of each alert are tracked and logged by the system.

5. Use of clinically identified ADEs. ADEs (adverse drug events) are valuable data for analyzing drug use and medication-related CDS. In China, we have a multilevel ADE reporting mechanism. Level I: Physicians submit detected ADE and related clinical data (patient demographics, symptoms, drug use info, etc.) to the hospital's pharmacy department. Level 2: Pharmacists submit confirmed ADEs to drug regulatory authorities, i.e. China SFDA (a counterpart of US FDA). Level 3: China SFDA evaluates drug risks based on nation-wide collected ADEs. Although this ADE-reporting mechanism is well designed, it's a sad reality that it hasn't lived up to its maximum benefit, largely due to the wide-spread under-reporting problems. Most ADE events were concealed or neglected in daily practices, and the few reported ADEs cannot be used as a solid and complete data source for analyzing physicians' drug use and evaluating our rule set. To address this issue, we are currently cooperating with clinical pharmacists to detect unreported ADEs from clinical documents (e.g. patient daily progress notes) by natural language processing (NLP) technologies.

6. Coverage of the rule set. One basic assumption of this study is that drug alerts conform to Pareto-alike distribution, where small portion of drug rules accounts 
for the majority of alerts. As a supporting case, one US study in 2005 (Reichley et al. 2005) used a commercial drug alerting rule set. It contains 48,262 rules for 1537 drugs, but $90 \%$ of alerts are focused on 58 drugs. From their daily work experience, the pharmacists in DaYi hospital also hold the same opinion that small set of drugs generate majority of errors. However, to further verify this assumption, a further evaluation is needed to get the coverage rate of the rule set. This requires a full set for all drugs on the Chinese market, and a parallel comparison of the full set and concise set on a large-scale and long-term patient drug use data set. A coverage rate greater than $80 \%$ should be ideal. Otherwise, more rules may have to be added to the rule set.

7. Another problem of the rule set is how to keep up with the latest clinical evidence. Occasionally published guidelines or case reports will necessitate adding or revising rules. For example, the China SFDA (State Food and Drug Administration) periodically publish ADE (adverse drug events) reports collected all round the country. A well-maintained rule set should keep up with these public sources. Currently, our research team is developing a semi-automatic program based on NLP, which will help pharmacists extract structured contents from the public ADE reports.

Generally speaking, the overall $85.0 \%$ accept rate indicates the rule set has been well received by physicians [compared to the override rates reported in other recent studies, e.g. 53.6\% (Nanji et al. 2014), 87.6\% (Topaz et al. 2015)] and is effective in reducing pharmacists' workload. Moreover, the pharmacists are continually analyzing (i.e. analyze those drug alerts with high override rates), improving (e.g. raise alert threshold to reduce false positive alerts) and expanding (i.e. add more drugs and rules) the drug rule set, which will further improve its accuracy and coverage. However, due to the various complex and individualized patient statuses, such a computerized rule set is never meant to substitute the routine work of pharmacists, but can be used an effective supportive tool.

\section{Conclusions}

In this study, a concise drug alerting rule set for Chinese hospitals was constructed by pharmacists. The case study in a Chinese hospital indicates the medication-related CDS based on the rule set has been well received by physicians. For other hospitals, they may use this rule set as a starter kit for building their own medication-related CDS systems or use it to tier commercial rule bases.

\section{Authors' contributions \\ $Y Z$ and $X L$ made the data analysis and wrote the manuscript. WC provided clinical advisory opinions to the study result. $\mathrm{HL}$ and $\mathrm{HD}$ supervised the entire study. QS further processed the results, and made the graphs and charts. All authors read and approved the final manuscript.}

\section{Author details}

${ }^{1}$ School of Computer Science and Information Engineering, Zhejiang Gongshang University, Hangzhou 310018, Zhejiang, People's Republic of China. ${ }^{2}$ College of Biomedical Engineering and Instrument Science, Zhejiang University, Hangzhou 310027, Zhejiang, People's Republic of China. ${ }^{3}$ Department of Pharmacy, DaYi Hospital, Taiyuan 030012, ShanXi, People's Republic of China. ${ }^{4}$ Children's Hospital, Institute of Translational Medicine, School of Medicine, Zhejiang University, Hangzhou 310058, Zhejiang, People's Republic of China. ${ }^{5}$ Management School, Hangzhou Dianzi University, Hangzhou 310058, Zhejiang, People's Republic of China.

\section{Competing interests}

The authors declare that they have no competing interests.

\section{Availability of data and materials}

Please contact corresponding author for data request.

\section{Funding}

This study is supported by Chinese National High-tech R\&D Program (2012AA02A601), Humanities and Social Sciences Foundation of Ministry of Education of China (15YJC630106), and Natural Science Foundation of Zhejiang Province of China (LQ16G020006). This study is also supported by the Research Center of Information Technology \& Economic and Social Development, Zhejiang Province, China.

\section{Appendix}

See Tables 4 and 5. 
Table 4 Drug rule set (Part 1)

\begin{tabular}{|c|c|c|c|}
\hline Drug & Drug (Chinese name) & Rule content & Rule type \\
\hline Compound matrine injection ${ }^{a}$ & 复方苦参注射液a & 2-3 dose & Dosage \\
\hline Injection aescinate ${ }^{a}$ & 注射用七叶皇苷钠 ${ }^{a}$ & $10-20 \mathrm{mg}$ & Dosage \\
\hline Injection of Ginkgo biloba extract ${ }^{\mathrm{a}}$ & 银杏叶提取物注射液 ${ }^{\mathrm{a}}$ & $\leq 4$ dose & Dosage \\
\hline Salvia ligustrazine injection ${ }^{\mathrm{a}}$ & 丹参川芎嗪注射液a & $\leq 2$ dose & Dosage \\
\hline Ambroxol injection & 盐酸氨溴索注射液 & $\leq 2$ dose & Dosage \\
\hline Phosphate sodium for injection & 磷酸钠注射液 & $\leq 2$ dose & Dosage \\
\hline Thin chi glycopeptide injection ${ }^{\text {a }}$ & 薄芝糖肽注射液 ${ }^{a}$ & $\leq 2$ dose & Dosage \\
\hline Citicoline injection & 胞二磷胆碱注射液 & $\leq 2$ dose & Dosage \\
\hline Tiopronin injection & 硫普罗宁注射液 & $\leq 2$ dose & Dosage \\
\hline Injection cefathiamidine & 注射用头孢硫脒 & $\leq 1$ dose & Dosage \\
\hline ShuXueNing injection ${ }^{a}$ & 舒血宁注射液 ${ }^{\mathrm{a}}$ & $\leq 2$ dose & Dosage \\
\hline Injection esomeprazole & 注射用埃索美拉唑 & $20-40 \mathrm{mg}$ & Dosage \\
\hline Flurbiprofen injection & 氟比洛芬酯注射液 & $50 \mathrm{mg}$ & Dosage \\
\hline Injection lentinan & 注射用香菇多糖 & $1 \mathrm{mg}$ & Dosage \\
\hline Hydrocortisone injection & 氢化可的松注射液 & $50-100 \mathrm{mg}$ & Dosage \\
\hline Xiaoaiping injection ${ }^{\mathrm{a}}$ & 消癌平注射液 ${ }^{a}$ & $2-4 \mathrm{ml}$ & Dosage \\
\hline Calcium gluconate injection & 葡萄糖酸钲注射液 & $1-2 \mathrm{~g}$ & Dosage \\
\hline Sodium phosphate injection & 注射用磷酸肌酸钠 & $\leq 1$ dose & Dosage \\
\hline Javanica oil emulsion injection ${ }^{a}$ & 鸦胆子油乳注射液a & $10-30 \mathrm{ml}$ & Dosage \\
\hline Injection ulinastatin & 注射用乌司他丁 & $100,000 U$ & Dosage \\
\hline Injection of Ginkgo biloba extract ${ }^{a}$ & 银杏叶提取物注射液a & 5 dose & Daily dosage \\
\hline Compound matrine injection ${ }^{\mathrm{a}}$ & 复方苦参注射液 ${ }^{a}$ & 3 dose & Daily dosage \\
\hline Salvia ligustrazine injection ${ }^{\mathrm{a}}$ & 丹参川芎嗪注射液 ${ }^{a}$ & 2 dose & Daily dosage \\
\hline Ambroxol injection & 盐酸氨溴索注射液 & 2 dose & Daily dosage \\
\hline Phosphate sodium for injection & 磷酸钠注射 & 2 dose & Daily dosage \\
\hline Thin chi glycopeptide injection ${ }^{\mathrm{a}}$ & 薄芝糖肽注射液 ${ }^{a}$ & 2 dose & Daily dosage \\
\hline Citicoline injection & 胞 (二) 磷胆碱注射液 & 2 dose & Daily dosage \\
\hline Tiopronin injection & 硫普罗宁注射液 & 2 dose & Daily dosage \\
\hline Injection aescinate ${ }^{a}$ & 注射用七叶㿝苷钠 ${ }^{\mathrm{a}}$ & $20 \mathrm{mg}$ & Daily dosage \\
\hline Injection cefathiamidine & 头孢硫脒注射液 & 1 dose & Daily dosage \\
\hline Injection of fat-soluble vitamins I & 注射脂溶性维生素 I & 1 dose & Daily dosage \\
\hline Injection of fat-soluble vitamins II & 注射脂溶性维生素II & 1 dose & Daily dosage \\
\hline Injection of water-soluble vitamins & 注射用水溶性维生素 & 1 dose & Daily dosage \\
\hline L-carnitine injection & 左旋肉碱注射液 & Iv push & Administration route \\
\hline Omeprazole injection (Losec) & 奥美拉唑注射液（罗塞克） & Iv push & Administration route \\
\hline Omeprazole injection (AoXiKang, Luoren) & 奥美拉唑注射液（奥西康, 罗润） & Iv drip & Administration route \\
\hline Injection thymopentin & 注射用胸腺五肽 & $\begin{array}{l}\text { Intramuscular injection, subcuta- } \\
\text { neous injection }\end{array}$ & Administration route \\
\hline Injection cobamamide & 注射用腺苷钴胺 & Intramuscular injection & Administration route \\
\hline Ambroxol injection & 盐酸氨溴索注射液 & IV & Administration route \\
\hline Furosemide injection & 呋塞米注射液 & IV & Administration route \\
\hline Pantoprazole injection & 注射用泮托拉唑 & Iv drip & Administration route \\
\hline Pancreatic kininogenase for injection & 注射用胰激肽原酶 & Intramuscular injection & administration route \\
\hline Leucovorin injection & 亚叶酸钻注射液 & Iv drip & Administration route \\
\hline L-carnitine injection & 左卡尼汀注射液 & IV & Administration route \\
\hline Heparin sodium injection & 肝素钠注射液 & Subcutaneous injection, iv & Administration route \\
\hline Alprostadil injection & 前列地尔注射液 & IV & Administration route \\
\hline Ceftriaxone for injection & 头孢曲松钠注射液 & 1/day & Frequency \\
\hline Injection esomeprazole & 注射用埃索美拉唑 & 1/day, 1/12 h & Frequency \\
\hline Leucovorin injection & 亚叶酸钻注射液 & $1 /$ day, $1 / 6 \mathrm{~h}$ & Frequency \\
\hline
\end{tabular}


Table 4 continued

\begin{tabular}{|c|c|c|c|}
\hline Drug & Drug (Chinese name) & Rule content & Rule type \\
\hline Injection torasemide & 注射用托拉塞米 & 1/day & Frequency \\
\hline Torasemide injection & 托拉塞米注射液 & 1/day & Frequency \\
\hline Injection ulinastatin & 注射用乌司他丁 & 1-3/day & Frequency \\
\hline Lidocaine hydrochloride injection & 盐酸利多卡因注射液 & Skin test required & Skin Test \\
\hline Furosemide injection & 呋塞米注射液 & $\mathrm{NaCl}$, sterile water & Dissolvent \\
\hline Sodium heparin injection & 肝素钠注射液 & $\mathrm{NaCl}$, sterile water & Dissolvent \\
\hline Brain carnosine injection & 脑肌肽注射液 & $\mathrm{NaCl}, 5 \%$ glucose & Dissolvent \\
\hline Tanreqing injection ${ }^{\mathrm{a}}$ & 痰热清注射液 ${ }^{\mathrm{a}}$ & $\mathrm{NaCl}, 5 \%$ glucose & Dissolvent \\
\hline Pantoprazole injection & 注射用泮托拉唑 & $\mathrm{NaCl}$ & Dissolvent \\
\hline Injection carbazochrome sodium sulfonate & 注射用卡络磺钠 & $\mathrm{NaCl}$ & Dissolvent \\
\hline Edaravone injection & 依达拉奉注射液 & $\mathrm{NaCl}$ & Dissolvent \\
\hline Lipoic acid injection & 硫辛酸注射液 & $\mathrm{NaCl}$ & Dissolvent \\
\hline Xuebijing injection ${ }^{\mathrm{a}}$ & 血必净注射液 ${ }^{\mathrm{a}}$ & $\mathrm{NaCl}$ & Dissolvent \\
\hline Iron sucrose injection & 蔗糖铁注射液 & $\mathrm{NaCl}$ & Dissolvent \\
\hline Injection of fat-soluble vitamins I & 注射脂溶性维生素 I & Glucose, sterile water & Dissolvent \\
\hline Injection of fat-soluble vitamins II & 注射脂溶性维生素II & Glucose, sterile water & Dissolvent \\
\hline Paclitaxel liposome for injection & 紫杉醇脂质体注射液 & Glucose, sterile water & Dissolvent \\
\hline Injection of liposomal amphotericin B & 注射用两性霉素B脂质体 & Glucose, sterile water & Dissolvent \\
\hline Polyene phosphatidylcholine injections & 多烯磷脂酰胆碱注射液 & Glucose, sterile water & Dissolvent \\
\hline Injection breviscapine ${ }^{a}$ & 注射用灯盏花素a & $\begin{array}{l}5 \% \text { glucose, } 10 \% \text { glucose, } 0.9 \% \\
\quad \mathrm{NaCl}\end{array}$ & Dissolvent \\
\hline Aminophylline injection & 氨茶碱注射液 & Glucose & Dissolvent \\
\hline Injection of Ginkgo biloba extract ${ }^{\mathrm{a}}$ & 银杏叶提取物注射液 ${ }^{a}$ & Glucose & Dissolvent \\
\hline Amiodarone injection & 胺碘酮注射液 & $5 \%$ glucose & Dissolvent \\
\hline Injection pHGF & 注射用促肝细胞生长素 & $10 \%$ glucose & Dissolvent \\
\hline Ginkgo leaf extract and dipyridamole injection ${ }^{a}$ & 银杏达莫注射液 ${ }^{\mathrm{a}}$ & $\begin{array}{l}0.9 \% \mathrm{NaCl}, 5 \% \text { glucose, } 10 \% \\
\text { glucose }\end{array}$ & Dissolvent \\
\hline Omeprazole injection & 奥美拉唑注射液 & $0.9 \% \mathrm{NaCl}$ & Dissolvent \\
\hline Calcium gluconate injection & 葡萄糖酸钲注射液 & $10 \%$ glucose & Dissolvent \\
\hline Oxytocin injection & 缩宫素注射液 & $\mathrm{NaCl}$ & Dissolvent \\
\hline TanReQing injection ${ }^{\mathrm{a}}$ & 痰热清注射液 & $5 \%$ glucose & Dissolvent \\
\hline ShuXueNing injection ${ }^{a}$ & 舒血宁注射液 ${ }^{a}$ & $5 \%$ glucose & Dissolvent \\
\hline Ginkgo leaf extract and dipyridamole Injection ${ }^{\mathrm{a}}$ & 银杏达莫注射液 ${ }^{a}$ & $500 \mathrm{ml}$ & Dissolvent dosage \\
\hline Levofloxacin & 左氧氟沙星 & $250 \mathrm{ml}$ & Dissolvent dosage \\
\hline Pantoprazole injection & 注射用泮托拉唑 & $100 \mathrm{ml}$ & Dissolvent dosage \\
\hline Xuebijing injection $^{\mathrm{a}}$ & 血必净注射液 ${ }^{a}$ & $100 \mathrm{ml}$ & Dissolvent dosage \\
\hline Iron sucrose injection & 蔗糖铁注射液 & $\leq 100 \mathrm{ml}$ & Dissolvent dosage \\
\hline Injection esomeprazole & 注射用埃索美拉唑 & $100 \mathrm{ml}$ & Dissolvent dosage \\
\hline Omeprazole injection & 奥美拉唑注射液 & $100 \mathrm{ml}$ & Dissolvent dosage \\
\hline Salvia ligustrazine injection ${ }^{\mathrm{a}}$ & 丹参川芎嗪注射液 ${ }^{\mathrm{a}}$ & $250-500 \mathrm{ml}$ & Dissolvent dosage \\
\hline Large plants Rhodiola injection ${ }^{\mathrm{a}}$ & 大株红景天注射液 ${ }^{\mathrm{a}}$ & $250 \mathrm{ml}$ & Dissolvent dosage \\
\hline Triazolam tablets & 三唑仑片 & $\begin{array}{l}\text { FDA pregnancy category } X \text {-use } \\
\text { on pregnant women is forbid- } \\
\text { den }\end{array}$ & Pregnancy risk \\
\hline Ribavirin & 利巴韦林 & & Pregnancy risk \\
\hline Estradiolvalerate & 戊酸雌二醇片 & & Pregnancy risk \\
\hline Fluorouracil Injection & 氟尿嘧啶注射液 & & Pregnancy risk \\
\hline Misoprostol tablets & 米索前列醇片 & & Pregnancy risk \\
\hline Simvastatin & 辛伐他汀 & & Pregnancy risk \\
\hline Avi A capsules & 阿维A胶囊 & & Pregnancy risk \\
\hline
\end{tabular}


Table 4 continued

\begin{tabular}{|c|c|c|c|}
\hline Drug & Drug (Chinese name) & Rule content & Rule type \\
\hline Estazolam tablets & 艾司唑仑片 & \multirow{31}{*}{$\begin{array}{l}\text { Restricted antibiotics. Only chief } \\
\text { physicians and above have the } \\
\text { prescription right. Resident phy- } \\
\text { sicians cannot directly prescribe } \\
\text { these drugs }\end{array}$} & Pregnancy risk \\
\hline Bicalutamide tablets & 比卡鲁胺片 & & Pregnancy risk \\
\hline Goserelin acetate sustained-release implants & 醋酸戈舍瑞林缓释植入剂 & & pregnancy risk \\
\hline Finasteride tablets & 非那雄胺片 & & Pregnancy risk \\
\hline Fluvastatin & 氟伐他汀 & & Pregnancy risk \\
\hline Fluorouracil implants & 氟尿嘧啶植入剂 & & Pregnancy risk \\
\hline Mifepristone misoprostol tablets & 米非司酮米索前列醇片 & & Pregnancy risk \\
\hline Levonorgestrel & 左炔诺孕酮 & & Pregnancy risk \\
\hline Estradiol & 雌二醇 & & Pregnancy risk \\
\hline Injection cefamandole ester & 注射用头孢孟多酯 & & Prescription restriction \\
\hline Injection cefoxitin & 注射用头孢西丁 & & Prescription restriction \\
\hline Sodium for injection cefodizime & 注射用头孢地嗪钠 & & Prescription restriction \\
\hline $\begin{array}{l}\text { Injectable piperacillin sodium and tazobactam } \\
\text { sodium }\end{array}$ & 注射用哌拉西林钠他唑巴坦钠 & & Prescription restriction \\
\hline Cefoperazone sulbactam & 注射用头孢哌酮舒巴坦 & & Prescription restriction \\
\hline Cefoperazone & 注射用头孢哌酮 & & Prescription restriction \\
\hline Ceftazidime for injection & 注射用头孢他啶 & & Prescription restriction \\
\hline Injection imipenem cilastatin sodium & 注射用亚胺培南西司他丁钠 & & Prescription restriction \\
\hline Meropenem for injection & 注射用美罗培南 & & Prescription restriction \\
\hline Fluconazole injection & 氟康唑注射液 & & Prescription restriction \\
\hline Vancomycin injection & 注射用万古霉素 & & Prescription restriction \\
\hline Itraconazole oral solution & 伊曲康唑口服液 & & Prescription restriction \\
\hline Minocycline hydrochloride capsules & 盐酸米诺环素胶囊 & & Prescription restriction \\
\hline Moxifloxacin injection & 莫西沙星注射液 & & Prescription restriction \\
\hline Injectable piperacillin sulbactam & 注射用哌拉西林舒巴坦 & & Prescription restriction \\
\hline Injection voriconazole & 注射用伏立康唑 & & Prescription restriction \\
\hline Azithromycin for injection & 注射用阿奇電素 & & Prescription restriction \\
\hline Injection caspofungin & 注射用卡泊芬净 & & Prescription restriction \\
\hline Injection teicoplanin & 注射用替考拉宁 & & Prescription restriction \\
\hline Linezolid injection & 利奈唑胺注射液 & & Prescription Restriction \\
\hline Moxifloxacin tablets & 莫西沙星片 & & Prescription restriction \\
\hline Injection of amphotericin B liposome & 注射用两性霉素B脂质体 & & Prescription restriction \\
\hline
\end{tabular}

a Chinese patent medicine 
Table 5 Drug rule set (Part 2: DDI pairs)

\begin{tabular}{|c|c|c|c|c|}
\hline Drug 1 & & Drug 2 & & Description \\
\hline Vitamin C injection & 维生素C注射液 & Vitamin $\mathrm{K} 1$ injection & 维生素K1注射液 & Mixture prone to turbidity ${ }^{\mathrm{a}}$ \\
\hline Four-vitamin injection & $\begin{array}{l}\text { 复方维生素注射 } \\
\text { 液 }(4)\end{array}$ & $\begin{array}{l}\text { Injection of fat-soluble vitamins | } \\
\text { Injection of fat-soluble vitamins || }\end{array}$ & $\begin{array}{l}\text { 注射脂溶性维生素我 } \\
\text { 注射脂溶性维生素II }\end{array}$ & $\begin{array}{l}\text { Same ingredient. Duplicate } \\
\text { therapy }^{\mathrm{a}}\end{array}$ \\
\hline $\begin{array}{l}\text { Methylprednisolone sodium suc- } \\
\text { cinate for injection }\end{array}$ & $\begin{array}{l}\text { 甲泼尼龙琥珀酸 } \\
\text { 钠注射液 }\end{array}$ & Insulin injection & 胰岛素注射 & \multirow{3}{*}{$\begin{array}{l}\text { Methylprednisolone sodium } \\
\text { succinate for injection increases } \\
\text { requirements for insulin or } \\
\text { oral hypoglycemic agents in } \\
\text { diabetics }^{\mathrm{a}}\end{array}$} \\
\hline $\begin{array}{l}\text { Methylprednisolone sodium suc- } \\
\text { cinate for injection }\end{array}$ & $\begin{array}{l}\text { 甲泼尼龙琥珀酸 } \\
\text { 钠注射液 }\end{array}$ & $\begin{array}{l}\text { Recombinant human insulin } \\
\text { injection }\end{array}$ & 重组人胰岛素注射 & \\
\hline $\begin{array}{l}\text { Methylprednisolone sodium suc- } \\
\text { cinate for injection }\end{array}$ & $\begin{array}{l}\text { 甲泼尼龙琥珀酸 } \\
\text { 钠注射液 }\end{array}$ & $\begin{array}{l}\text { Protamine recombinant human } \\
\text { insulin injection }\end{array}$ & $\begin{array}{l}\text { 鱼精蛋白重组人胰岛 } \\
\text { 素注射液 }\end{array}$ & \\
\hline Salvia ligustrazine injection ${ }^{b}$ & $\begin{array}{l}\text { 丹参川芎嗪注 } \\
\text { 射液b }^{b}\end{array}$ & Vitamin K1 Injection & 维生素K1注射液 & Antagnistic effect ${ }^{a}$ \\
\hline Ginkgo biloba extract injection & $\begin{array}{l}\text { 银杏叶提取物注 } \\
\text { 射液 }^{b}\end{array}$ & $\begin{array}{l}\text { injection calf blood protein } \\
\text { extract }\end{array}$ & $\begin{array}{l}\text { 注射用小牛血去蛋白 } \\
\text { 提取物 }\end{array}$ & $\begin{array}{l}\text { Cause serious adverse effects, such } \\
\text { as gastrointestinal discomfort, } \\
\text { headache, decreased blood pres- } \\
\text { sure, allergic reactions }\end{array}$ \\
\hline \multirow[t]{14}{*}{ Selegiline } & \multirow[t]{14}{*}{ 司来吉兰 } & Pseudoephedrine & 伪麻黄碱 & \multirow{2}{*}{$\begin{array}{l}\text { MAO inhibitors_Amphetamine } \\
\text { and derivatives }\end{array}$} \\
\hline & & Diethylpropion & 二乙胺 & \\
\hline & & Fluoxetine & 氟西汀 & \multirow{8}{*}{$\begin{array}{l}\text { MAO inhibitors - selective seroto- } \\
\text { nin reuptake inhibitors (SSRIs) }\end{array}$} \\
\hline & & Paroxetine & 帕罗西汀 & \\
\hline & & Citalopram & 西酞普兰 & \\
\hline & & Escitalopram & 艾司西酞普兰 & \\
\hline & & Sertraline & 舍曲林 & \\
\hline & & Fluvoxamine & 氟伏沙明 & \\
\hline & & Duloxetine & 度洛西汀 & \\
\hline & & Venlafaxine & 文拉法辛 & \\
\hline & & Meperidine & 哌替啶 & \multirow{3}{*}{$\begin{array}{l}\text { MAO inhibitors-narcotic anal- } \\
\text { gesics }\end{array}$} \\
\hline & & Fentanyl & 芬太尼 & \\
\hline & & Tramadol & 曲马多 & \\
\hline & & Amitriptyline & 阿米替林 & $\begin{array}{l}\text { Selegiline-tricyclic antidepres- } \\
\text { sants (TCAs) }\end{array}$ \\
\hline \multirow[t]{10}{*}{ Irinotecan } & \multirow[t]{10}{*}{ 伊立替康 } & Clarithromycin & 克拉電素 & \multirow{10}{*}{$\begin{array}{l}\text { Irinotecan—strong CYP3A4 inhibi- } \\
\text { tors }\end{array}$} \\
\hline & & Erythromycin & 红霉素 & \\
\hline & & Amiodarone & 胺磺酮 & \\
\hline & & Verapamil & 维拉帕米 & \\
\hline & & Diltiazem & 地尔硫卓 & \\
\hline & & Ketoconazole & 酮康夾 & \\
\hline & & Itraconazole & 伊曲康唑 & \\
\hline & & Fluconazole & 氟康唑 & \\
\hline & & Voriconazole & 伏立康唑 & \\
\hline & & Cimetidine & 西咪替丁 & \\
\hline \multirow[t]{10}{*}{ Simvastatin } & \multirow[t]{10}{*}{ 辛伐他汀 } & Clarithromycin & 克拉霉素 & \multirow{9}{*}{$\begin{array}{l}\text { HMG Co-A reductase inhibitors- } \\
\text { CYP3A4 inhibitors }\end{array}$} \\
\hline & & Erythromycin & 红霉素 & \\
\hline & & Amiodarone & 胺碘酮 & \\
\hline & & Verapamil & 维拉帕米 & \\
\hline & & Diltiazem & 地尔硫卓 & \\
\hline & & Ketoconazole & 酮康唑 & \\
\hline & & Itraconazole & 伊曲康唑 & \\
\hline & & Fluconazole & 氟康唑 & \\
\hline & & Voriconazole & 伏立康唑 & \\
\hline & & Roxithromycin & 罗红電素 & $\begin{array}{l}\text { Severe DDI reported from litera- } \\
\text { ture, including rhabdomyolysis } \\
\text { and liver damage }\end{array}$ \\
\hline
\end{tabular}


Table 5 continued

\begin{tabular}{|c|c|c|c|c|}
\hline Drug 1 & & Drug 2 & & Description \\
\hline Ergotamine & 麦角胺 & Clarithromycin & 克拉需素 & Ergot alkaloids and derivatives- \\
\hline & & Erythromycin & 红霉素 & CYP3A4 inhibitors \\
\hline & & Ketoconazole & 酮康唑 & \\
\hline & & Itraconazole & 伊曲康唑 & \\
\hline & & Voreconazole & 伏立康唑 & \\
\hline Tizanidine & 替扎尼定 & Ciprofloxacin & 环丙沙星 & Tizanidine-CYP1A2 inhibitors \\
\hline & & Fluvoxamine & 氟伏沙明 & \\
\hline & & Mexiletine & 美西律 & \\
\hline & & Propafenone & 普罗帕酮 & \\
\hline & & Amiodarone & 胺碘酮 & \\
\hline Zolmitriptan & 佐米曲普坦 & Moclobamide & 吗氯贝胺 & Triptans-MAO inhibitors \\
\hline & & Methylene blue & 亚甲蓝 & \\
\hline Chloroquine & 氯喹 & QT prolonging as & drugs have s & fect \\
\hline Moxifloxacin & 莫西沙星 & & & \\
\hline Sotalol & 索他洛尔 & & & \\
\hline Clarithromycin & 克拉需素 & & & \\
\hline Citalopram & 西酞普兰 & & & \\
\hline Amiodarone & 胺碘酮 & & & \\
\hline Erythromycin & 红霉素 & & & \\
\hline Haloperidol & 氟哌啶醇 & & & \\
\hline Droperidol & 氟哌利多 & & & \\
\hline Domperidone & 多潘立酮 & & & \\
\hline Procainamide & 普鲁卡因胺 & & & \\
\hline Sevoflurane & 七氟醚 & & & \\
\hline Chlorpromazine & 氯丙嗪 & & & \\
\hline Arsenic trioxide & 白砒 & & & \\
\hline Azithromycin & 阿奇霉素 & & & \\
\hline
\end{tabular}

a Means these rules are added by the local pharmacists; others are from the work published by other researchers (Phansalkar et al. 2012)

b Chinese patent medicine

Received: 19 May 2016 Accepted: 18 November 2016 Published online: 01 December 2016

\section{References}

Andersson ML, Böttiger Y, Bastholm-Rahmner P et al (2015) Evaluation of usage patterns and user perception of the drug-drug interaction database SFINX. Int J Med Inform 84:327-333. doi:10.1016/j. ijmedinf.2015.01.013

Bryant A, Fletcher G, Payne T (2013) Drug interaction alert override rates in the meaningful use era: no evidence of progress. Appl Clin Inform 5:802-813. doi:10.4338/ACl-2013-12-RA-0103

Classen DC, Phansalkar S, Bates DW (2011) Critical drug-drug interactions for use in electronic health records systems with computerized physician order entry: review of leading approaches. J Patient Saf 7:61-65. doi:10.1097/PTS.0b013e31821d6f6e

Claus BO, Colpaert K, Steurbaut K et al (2015) Role of an electronic antimicrobial alert system in intensive care in dosing errors and pharmacist workload. Int J Clin Pharm 37:387-394. doi:10.1007/ s11096-015-0075-6
Hammar T, Lidström B, Petersson G et al (2015) Potential drug-related problems detected by electronic expert support system: physicians' views on clinical relevance. Int J Clin Pharm 37:941-948. doi:10.1007/ s11096-015-0146-8

Nanji KC, Slight SP, Seger DL et al (2014) Overrides of medication-related clinical decision support alerts in outpatients. J Am Med Inform Assoc 21:487-491. doi:10.1136/amiajnl-2013-001813

Phansalkar S, Desai AA, Bell D et al (2012) High-priority drug-drug interactions for use in electronic health records. J Am Med Inform Assoc 19:735-743. doi:10.1136/amiajn|-2011-000612

Reichley RM, Seaton TL, Resetar E et al (2005) Implementing a commercial rule base as a medication order safety net. J Am Med Inform Assoc 12:383-389. doi:10.1197/jamia.M1783

Shah NR, Seger AC, Seger DL et al (2006) Improving acceptance of computerized prescribing alerts in ambulatory care. J Am Med Inform Assoc 13:5-11. doi:10.1197/jamia.M1868

Topaz M, Seger DL, Slight SP et al (2015) Rising drug allergy alert overrides in electronic health records: an observational retrospective study of a decade of experience. J Am Med Inform Assoc. doi:10.1093/jamia/ocv143

Zhang Y, Li H, Duan H et al (2015) Mobilizing clinical decision support to facilitate knowledge translation: a case study in China. Comput Biol Med 60:40-50. doi:10.1016/j.compbiomed.2015.02.013 